\title{
Biomass Clusterization from a Regional Perspective: The Case of Lithuania
}

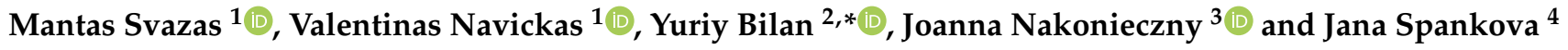 \\ 1 School of Economics and Business, Kaunas University of Technology, 44239 Kaunas, Lithuania; \\ mantas.svazas@ktu.lt (M.S.); valentinas.navickas@ktu.lt (V.N.) \\ 2 Faculty of Bioeconomy Development, Vytautas Magnus University, 44239 Kaunas, Lithuania \\ 3 Faculty of Management, Rzeszow University of Technology, 35-959 Rzeszow, Poland; \\ j.nakonieczny@prz.edu.pl \\ 4 Faculty of Social and Economic Relations, Alexander Dubček University of Trenčín, 91150 Trenčín, Slovakia; \\ jana.spankova@tnuni.sk \\ * Correspondence: y.bilan@prz.edu.pl
}

check for updates

Citation: Svazas, M.; Navickas, V.; Bilan, Y.; Nakonieczny, J.; Spankova, J. Biomass Clusterization from a Regional Perspective: The Case of Lithuania. Energies 2021, 14, 6993. https://doi.org/10.3390/en14216993

Academic Editor:

Oleksandr Melnychenko

Received: 28 September 2021

Accepted: 20 October 2021

Published: 25 October 2021

Publisher's Note: MDPI stays neutral with regard to jurisdictional claims in published maps and institutional affiliations.

Copyright: (c) 2021 by the authors. Licensee MDPI, Basel, Switzerland. This article is an open access article distributed under the terms and conditions of the Creative Commons Attribution (CC BY) license (https:// creativecommons.org/licenses/by/ $4.0 /)$.

\begin{abstract}
The usage of renewable resources has become inseparable from the further development of the world economy. To preserve a clean environment for future generations, the use of renewable resources is becoming inevitable even in less developed countries. Recently, the world is facing with challenges in securing green heat production. This situation allows the biomass energy sector to develop. Biomass extracted from waste enables to produce green energy, while contributing to the sustainable development of forestry. One of the major constraints on the usage of biomass is the complex and multifaceted supply chain involving different business subjects. Compatibility problems with different interests can be solved by operating in a cluster structure. Cluster activities allow for more efficient use of limited resources. It allows to create added value for the region and society. Due to the specificity of biomass energy, there is an opportunity to create regional business units that would involve human resources and solves long-standing social problems. The aim of the study is to show the progress of Lithuanian regions in using biomass resources for heat energy production. With the assistance of cluster analysis, it is performed based on economic, social, and environmental data of Lithuanian regions.
\end{abstract}

Keywords: biomass clusters; region's development; clusterization; cluster analysis

\section{Introduction}

The rising concern about global warming encourages investments in green energy solutions. Depending on the climate conditions and the abundance of natural resources available, countries in the world choose different ways of producing green energy. The developed Western European countries and the United States of America focus on electricity generation through the development of technologies using wind and solar resources. At the same time, the heat production sector faces several challenges: how to produce large amounts of energy without harming the environment, while at the same time replacing the polluting coal and natural gas fuels. Geothermal waters and biomass are mentioned in the scientific literature as cost-effective renewable energy sources [1-5]. However, the distribution of geothermal water resources in the world is uneven and the use of biomass allows the combined generation of both heat and electricity. In addition, biomass is environmentally neutral, as incineration produces only the amount of carbon dioxide that the plant has absorbed during its life cycle. In other cases, the use of biomass for energy production has a positive impact on the economy: the processing of biomass in a biogas reactor allows the release and incineration of hazardous methane gas, which would otherwise be released directly into the planet's atmosphere. All these factors have created a situation where biomass is one of the most cost-effective solutions for green energy production. 
The cluster concept is based on cooperation between different entities in a certain region and striving for the common aim. In the classical cluster structure financial, human, and intellectual resources are concentrated to achieve the cluster's activity objectives. The phenomenon under analysis in the article is of relevance in two aspects. As regards the first aspect, there is a lack of research to demonstrate the action of a biomass cluster in a certain area. In the second case, it is stated that the biomass cluster is designed to satisfy the energy needs of a certain region or a group of regions. This is fundamentally different from the classic concept of clusters, where resources and work in a cluster are directed at national or export markets as a whole. The activities of the biomass cluster are reserved exclusively for the region of activity, the sustainable use of the resources it contains and the enrichment of the region. The uncertainty of the existing synergistic effects and the resulting difficulties in characterizing the positive effect of the conversion of biomass make it necessary to identify positive trends in the effects of the biomass cluster and to define the market structure factors that support and influence the current activity of the biomass cluster.

The clustering of the biomass sector as an energy unit is relatively poorly investigated. Scientists turned to the idea of the use of biomass to meet energy needs only about a decade ago. The scientific problem is addressed through several different aspects, the studies are fragmentary and there are no developed research trends and topics of particular relevance. The regional dimension is observed, i.e., in different continents ways of usage of different types of biomass and their impacts are investigated. A number of studies on the potential of usage of biomass in industrial clusters have been carried out [6-10]. In this case, biomass is considered to be a secondary factor meeting the energy needs of industrial clusters. In this way the scientists are investigating how industrial clusters start converting biomass, but industrial entities of biomass have not been seen as an important part of the cluster. They are treated as service providers and ensures of energy supply. The recent articles have examined different types of biomass, such as woody biomass, methanol and different types of algae.

In most of the studies there is a lack of economic assessment. The combined technicaleconomic assessment prevails, when the technical perspective is distinguished, while the economic factors are treated as important, but do not determine the decision of technical modernization [11-13]. Studies have also been carried out where the use of biomass is combined with the use of other fuels [14-16]. There is no specific emphasis on the energy consumption target here: in one case it may be clustered rural areas and in the other case different groups of business and private customers. Biomass plays a significant role in energy production, but it is combined with other forms of energy. In this case the technical and political characteristics are also emphasized, but there is a lack of in-depth economic assessment.

The aim of the article - to investigate the impact of the use of biomass on regional development in the aspect of sustainable development. This includes different economic indicators of the regions, the connection of which allows to study the comprehensive development of the regions.

\section{Literature Review}

Biomass clustering processes take place exclusively in regional areas, close to existing biomass resources-forests, unused land areas, plantations of energy crops. It creates regional distinctiveness-fully clustered activities in cities would not be possible. Involving specialists of different profiles solving regional problems, such as long-term unemployment, lack of capital, and a wide range of social problems. However, biomass energy has longstanding barriers to development, which in many cases are due to a lack of political will. Regions, that have been able to see the benefits of using biomass more quickly have developed relatively faster. Development is based on the usage of local resources, thus leaving all the value created within the region.

In general, researchers single out various types of barriers that prevent the development of biomass energy. At the same time, it limits the scope for clustering of the 
sector. One of the main barriers is related to raising capital, (Table 1), but infrastructure and social aspects are also important. Reducing the impact of these barriers would create preconditions for concentrating corporate resources in clusters and using them to occupy new markets. To ensure the financial side of the activity, it is also necessary to work with the social partners - to acquaint them with the concept of clusters, to clarify the impact of the activity, to present the benefits of the activity to the society. In this way, threats arising from information asymmetry and misinformation can be eliminated.

Table 1. Barriers to biomass energy development.

\begin{tabular}{cc}
\hline Source & Identified Barriers \\
\hline$[17]($ Czechia, 2014) & Information flows \\
{$[18]($ Northern Italy, 2016) } & Failure to comply the national laws \\
{$[$ [19] (Denmark, 2016) } & \\
\hline$[17]($ Devens, MA, 2016) & Unskilled human resources \\
{$[21]($ Spain, 2009) } & Technological issues \\
\hline$[20]($ Devens, MA, 2016) & \\
\hline 18$]($ Northern Italy, 2016) & Lack of information \\
\hline$[18]($ Northern Italy, 2016) & \\
\hline 21$]($ Spain, 2009) &
\end{tabular}

One of the biggest obstacles in biomass energy sector is technical barriers. It can significantly limit the spread of biomass energy, interfere investment and energy progress. From the point of view of [22], given the obvious inevitable issues related to fossil fuels, including the availability of fossil fuels in the coming years, renewable energy may be the positive path for the future of energy production sector. However, consumption patterns are also changing and the demand for a new product depends on the added value created in terms of economic, social and environmental benefits. New products must be technologically and economically viable to be successful. According to Dasappa [23], presents some possible technical barriers with an economic basis:

- Biomass resources and geographical distribution;

- $\quad$ Biomass (wood waste and crop residues) demand (energy, feed, etc.) and geographical distribution;

- $\quad$ Electricity demand and possible growth of electricity demand (with increasing electrification) according to geographical distribution;

- Identification of potential regions with compatibility of available resources and energy needs;

- Technical aspects of gasification;

$\bigcirc \quad$ Norms and standards for renewable energy efficiency, production, installation and maintenance are weak and/or non-existent.

Lack of collection points for locally produced renewable energy technology components without exploiting the region's concentrated knowledge, skills and experience in operating renewable energy systems.

Limited technical capabilities to design, install, operate, manage and maintain local grids (renewable mini-grids).

Biomass energy sector efficiency maintains cluster activities and solve particular problems [24]. Opportunities for the development of a biomass cluster that are relevant to countries that do not have a deep tradition of operating in the sector. Incentive instruments can be used in the early stages of operation to develop the acceleration of activity. According to the researchers, the new capable energy production cluster should be significantly supported by some coordinated government policy. Various options for the development of an energy cluster are possible, but any solution is likely to require changes in tax 
policy and include tax incentives, "tax holidays", initial investment grants, voluntary upgrading of infrastructure (e.g., roads to power plants or biomass concentration places) and public/private transport. private sector partnerships. Meanwhile, [25] distinguishes the main project performance indicators:

- Optimization of key production indicators-economic activity (sales volume, profitability, capital productivity, etc.) in the cluster members;

- Increase in tax revenue;

- Growth of attracted investments, including foreign funds and private investments;

- Increase in the number of companies and organizations, including SMEs, participating in the cluster;

- Increasing the number of skilled jobs, including the involvement of high-tech experts.

The activities of the biomass cluster create a wide range of macroeconomic impacts, which are assessed on a regional and national scale. Business clustering initiates an extensive social redistribution, which manifests itself in the creation of unskilled jobs, the reduction of unemployment, increased stability, and changes in environmental protection, development and regional policy. The use of biomass is desirable for several reasons, including energy security factors, environmental concerns, foreign exchange savings, and socioeconomic issues [26]. Synergistic effects arising from biomass clustering permit the reorientation of both the energy system and the regional economy.

Creation of the new workplaces is a key part of economic development. Positive effects are not limited to the amount of wages paid. The positive effect occurs when workers spend part of their income in the local economy, creating additional benefits, thus creating a multiplier effect. The increased costs create economic activity (jobs and income) in other sectors, such as retail, restaurants, the leisure sector, and entertainment. Renewable energy systems can create more workplaces per unit of money invested than conventional energy supply projects. The number of workplaces also depends on the number of production stages carried out in the region, as more jobs will be created if materials and technologies are recycled and produced locally [27]. The growth of taxes on labor relations is directly reflected in national and social security budgets, and additional funds can be directed to protect the most vulnerable sections of society from further stagnation. Biomass energy can create many jobs in the internal market, and it is guaranteed that many of these jobs will not be relocated due to the locality of resources [28]. Funds invested in energy efficiency measures generate cash flows that can be channeled to stimulate the economy and new workplaces creation.

Finally, it must be emphasized that the impact of biomass clusters is not limited to reduced pollution levels and improved bio-waste management. The use of biomass in energy facilitates the development of a sustainable society. A sustainable society is envisioned as an assembly of people capable of using limited resources sustainably. It is also added that one of the factors necessary for the sustainable development of society is the decreasing or at least not increasing total energy consumption [29]. Biomass clusters can contribute to this by offering consumers a shift to more efficient energy solutions. By maintaining constant communication with energy consumers, the cluster can steer them on the path to changes in energy consumption.

Summarizing the impact of the biomass cluster on the economy, it can be predicate that the impact is both direct (development of a new business sector) and indirect (exploitation of local resources by cleaning the environment, solving social problems while creating value). The impact of the cluster is based on synergies- the factors of local resource use together strengthen energy security, economic viability of regions, improve the state of the environment. The activities of the cluster emphasize the link between the principles of sustainable development-it is inseparable from the daily activities of the cluster and is the main factor ensuring competitiveness. 


\section{Materials and Methods}

The methodology uses data related to sustainable development in the regional areas. The example of Lithuania is used for the research. In the country since 2009 the use of biomass resources has increased by more than $70 \%$. The growth of biomass use in Lithuania developed according to the principles of clustering-strong biomass preparation and processing sectors were created, and producers of equipment using biomass emerged. At the same time, there is a constant exchange of scientific information, which has made it possible to develop more efficient equipment and reduce fuel production losses. By cooperating with each other, business entities were able to supply regional centers with biomass, thus reducing the cost of heat. Prior to the use of biomass, imported natural gas was used for heat production. Production and consumption of biomass on the principle of clustering is formed naturally, forming the whole market. Nevertheless, research lacks a scientific rationale for how the use of biomass affects national and regional economies. The prevailing situation in the country is fully in line with the goals of the European Union's Green deal-to reduce carbon dioxide emissions and promote green energy production. The impact of biomass use in this work is assessed on the basis of data defining sustainable development. The use of biomass is inseparable from the desire to decarbonization, which has social and economic consequences. Together with environmental data, these three groups of criteria are distinguished. These criteria include the directions of impact that the biomass cluster operates during its activities. In one case, new value is created (products not used before), in another case savings and increased operational efficiency are observed. From an environmental point of view, progress in environmental management due to the positive financial impact is highlighted (Table 2).

Table 2. Required data for the research.

\begin{tabular}{|c|c|c|c|}
\hline Criteria Group & Criterion & Unit & Source of Data \\
\hline \multirow{6}{*}{ Economic perspective } & Municipal (regional) budget revenues & $€$ & \multirow{6}{*}{ [30-34] } \\
\hline & $\begin{array}{c}\text { Municipal (regional) budget } \\
\text { expenditures }\end{array}$ & $€$ & \\
\hline & Personal income tax revenues & $€$ & \\
\hline & Costs for biomass & $€$ & \\
\hline & Costs for gas & $€$ & \\
\hline & Heat price & $€_{\mathrm{ct}} / \mathrm{kWh}$ & \\
\hline \multirow{3}{*}{ Social perspective } & Costs for social allowance & $€$ & \multirow{3}{*}{ [30] } \\
\hline & Average wage & $€$ & \\
\hline & Unemployed persons & Persons & \\
\hline $\begin{array}{l}\text { Environmental } \\
\text { perspective }\end{array}$ & $\begin{array}{l}\text { Forest management projects } \\
\text { Forest coverage level }\end{array}$ & $\begin{array}{l}\text { ha } \\
\%\end{array}$ & [35] \\
\hline
\end{tabular}

Data were processed and adapted for this study before use. Until 2015 the litas currency circulated in Lithuania, after which the litas was replaced by the single EU currency, the euro. All data presented in litas were converted into euros. In some cases, when data were provided in the format of counties or other regional compounds, they were disaggregated by assigning a particular regional part. In the case of gas and biomass costs, the amount of costs by municipality was determined by considering the amount of fuel consumed, multiplied by the prevailing fuel price at that time. In the absence of a contribution of GDP by municipalities, based on the theoretical analysis, the impact of the use of biomass on economic, social, and environmental cohesion was chosen to be studied. This has led to a more complex study, covering not only economic factors but also the importance of biofuel actions for the main levels of activity in the region.

Cluster analysis is used to group regions according to certain characteristics. According to the available data, the regions are divided into clusters, which are then used for other analytical activities. Regions in clusters are united by similar characteristics and development scenarios. In this case, clustering of time series is distinguished, as the available 
data relate to a certain analyzed period, allowing to compare different regions according to the degree of sustainable energy development. Clustering methods are applied in many fields, including artificial intelligence and model recognition, ecology, economics, geology, marketing, medical research, political science, psychometry, and others [36]. Cluster analysis is unique in that its goal is to reduce the number of cases or observations by dividing them into homogeneous groups, identifying groups without knowing in advance group membership or the number of possible groups [37]. Cluster analysis also provides many possibilities related to the grouping algorithm, with each choosing a different grouping structure. Therefore, cluster analysis can be a convenient statistical tool for studying the basic structures of different types of data sets. The uniqueness of the cluster analysis is related to the possibility to group the components of different capacities according to certain selected criteria, creating conditions for comparing the components.

The two most widely used methods of cluster analysis are mentioned in the scientific literature-hierarchical clustering and K-Mean clustering. This procedure is an exploratory tool designed to reveal natural groups (or clusters) of a data set that cannot be detected. The algorithm used by this method has a significant amount of desired properties that make it different from other methods [38]:

1. Application of categorical and continuous variables: Assuming that the variables are independent, a general multinomial-normal distribution can be established for the categorical and continuous variables.

2. Automatic selection of some clusters: By comparing the values of the model selection criterion in different clustering solutions, the procedure can automatically determine the optimal number of clusters.

3. Scaling: A group property tree is constructed that summarizes the number of optimal clusters.

With some data, the most appropriate clustering method can be applied. Before making a decision on the choice of method, it is necessary to carefully analyze the available data and know what result is sought. The methods can combine indicators of different dimensions, but of the same analysis period, by dividing them into clusters describing certain regularities. The methods used in cluster analysis differ in their specifics, data sample, level of data preparation. Choosing the incorrectly method could lead to inaccurate test results. Detailed analysis of clustering methods will allow us to accurately determine the need to use a particular method, avoiding further research errors. In addition, the presentation of different methods will allow us to justify the decision to choose one method of cluster analysis. A more detailed analysis of data clustering methods is presented in Table 3.

Table 3. The methods of cluster analysis.

\begin{tabular}{cc}
\hline Method & Specification \\
\hline [39-43] & $\begin{array}{c}\text { One of the most popular methods is K-Means, where each } \\
\text { cluster has a prototype calculated from the average of } \\
\text { objects in that group. The goal of this method is to } \\
\text { minimize the distance (scatter) between the objects in each } \\
\text { group. From this method, the k-meanoids method (PAM) } \\
\text { has evolved, where the prototype of each group contains a } \\
\text { real object whose value is closest to the group mean. For } \\
\text { both methods, the number of clusters must be defined in } \\
\text { advance. Applying fuzzy logic results in the Fuzzy } \\
\text { c-Means (FCM) method, where one value can belong to } \\
\text { several clusters and the number of clusters is selected } \\
\text { during optimization. }\end{array}$ \\
\hline
\end{tabular}


Table 3. Cont.

\begin{tabular}{ccc}
\hline Source & Specification \\
\hline & Probably the most widely used method is agglomerative \\
hierarchical cluster analysis. It is based on a proximity \\
matrix that includes an assessment of the similarity of all \\
object pairs. A variety of measures can be used to measure \\
the similarity or difference between different types of \\
variables (quantitative, qualitative, and binary). In addition, \\
it is often the case that clusters have sub-clusters, and \\
hierarchical structures naturally reflect the main scope. \\
Hownever, due to the complexity of the quadratic \\
calculation, it only applies to small data sets.
\end{tabular}

Grid-based clustering proceeds by dividing data space into a grid structure with a certain finite number of cells. Operations are then performed on all of these cells, not on individual data points. This method usually processes data [50-53] grid-based faster than other methods due to the reduced number of elements processed.

The considered time period is divided into a finite number of periods from which a grid is formed. The use of waves is a classic example of such a group of methods. This type of method is rarely used for time series clustering.

An attempt is made to reproduce the original model from a given data set by creating a separate model for each cluster and selecting the objects that best fit that model. The model-based model relies on finite models, where the density of each component typically represents a cluster.

[54-58] model-based The disadvantages of this group of methods are high computational costs, the requirement of a pre-known model format, and non-real-world process assumptions used to create the model. One way to handle large-scale data in a model-based approach is to use a factor analyzer model or some variants of it.

Density-based clustering proceeds on the principle that all data is considered as a single image of the density function, but those areas where more points are concentrated should be considered as those that can provide data analysis results. Clusters obtained on the basis of density-based clustering are summarized as separated by low-density

[59-63] density-based areas. Traditional density methods are DBSCAN, OPTICS, and DENCLUE. DBSCAN and its extension, OPTICS, are typical density methods that summarize groups based on density-based link analysis in a spatial data set. DENCLUE

is a method for classifying objects based on the value distribution analysis of density functions

At different levels, several of the above methods are applied or they are applied according to the different characteristics

[64-66] multi-step of the rows. E.g., applying the k-means object method to different metrics (line form and time) allows to find lines with similar properties with small computational resources.

Based on the cluster analysis methods presented in the table, was made the decision to use the division method using K-mean cluster analysis. The decision was made considering the available data and the objectives of the article. Researchers base the reasons for the use of the K-mean differently. The K-Mean clustering algorithm is a basic algorithm based on the decomposition method used for many clustering tasks, especially for small-sized data sets [67]. Using the K-mean clustering method, data are grouped according to their proximity to each other according to Euclidean distance. In this case, $\mathrm{k}_{\mathrm{y}}$ is accepted as an 
input parameter, thus dividing the set of $n$ objects into groups of $\mathrm{k}_{\mathrm{y}}$. The average value of an object is considered a similarity parameter when forming groups [68]. The cluster average or center is formed by randomly selecting a $\mathrm{k}_{\mathrm{y}}$ object. After comparing the existing similarities, the objects are assigned to a cluster. Cluster analysis assists to group regions into different characteristics. This makes it possible to single out regions with positive economic characteristics and areas whose energy performance needs to be improved. In the case of biomass clustering, regions with sufficient biomass resources can be studied $[69,70]$. used the Markov model in his study, which models different time series simultaneously. This model identifies groups of time series with similar dynamics that can be applied to the analysis of time series relationships, considering the heterogeneity of time series as well as the hidden states in the time series. This extended hidden Markov model can be useful for monitoring any consistent process. Based on the work of the presented researchers, it is assumed that the K-mean method will permit the division of the regions into such groups, which will summarize their chosen path of reorientation of the energy system, solution of social problems, use of local resources. At the same time, this method can be used with data of different dimensions, as is the case in this study. With usage of the method, it will be possible to see the progress or regression of regions over time, thus moving different clusters. Lithuanian municipalities with district heating networks are used to perform cluster analysis, excluding large cities. The latter municipalities are not considered to produce biomass but may be home to the parent biofuel companies. In this way, their results can significantly distort the overall situation.

In summary, the cluster analysis is appropriate for investigation the economies of regional areas, as the analysis examines different indicators. In the case of biomass clusters, indicators of sustainable development are studied, thus enabling to detect the leading regions. K-Mean clustering allows to use indicators of different dimensions as a unifying factor in emphasizing the time series. The research provides the progress of Lithuanian regions in the development of biomass energy, conveyed according to the link between sustainable development indicators.

\section{Results}

Analytical actions are performed based on cluster analysis elements. Two important components that characterize the data groups are analyzed-analysis of variance and determination of cluster centers. The results of analysis of variance are first considered. To do this, an F test is performed. It is generally accepted that variables with large F values best divide the data into certain clusters [70]. In this case, it is considered that certain indicators define the municipalities concentrated in different clusters. The results of the ANOVA analysis of variance presented in Table 4 show that several indicators stand out with particularly high values, thus enabling the grouping of data into different clusters. In order to unify the values and dimensions of the numbers, for the analysis are used normalized values.

Table 4. Results of variance analysis.

\begin{tabular}{|c|c|c|c|c|c|c|}
\hline & \multicolumn{2}{|c|}{ Cluster } & \multicolumn{2}{|c|}{ Error } & \multirow[t]{2}{*}{$\mathbf{F}$} & \multirow[t]{2}{*}{ Sig. } \\
\hline & Mean sq. & df & Mean sq. & df & & \\
\hline Zscore (Costs_for_biomass_EUR) & 1.351 & 2 & 0.137 & 467 & 9.868 & 0.000 \\
\hline Zscore (Costs_for_gas_EUR) & 0.246 & 2 & 0.048 & 467 & 5.148 & 0.006 \\
\hline Zscore (Costs_for_social_allowance_th_EUR) & 6.797 & 2 & 0.285 & 467 & 23.874 & 0.000 \\
\hline $\begin{array}{l}\text { Zscore: Municipal_budget_ } \\
\text { expenditures th_EUR }\end{array}$ & 0.108 & 2 & 0.035 & 467 & 3.134 & 0.044 \\
\hline Zscore: Municipal_budget_revenues_th_EUR & 0.134 & 2 & 0.036 & 467 & 3.716 & 0.025 \\
\hline Zscore (Personal_income_tax_revenues_EUR) & 0.760 & 2 & 0.041 & 467 & 18.498 & 0.000 \\
\hline Zscore (heat_price_euro_ct_kWh) & 98.625 & 2 & 0.568 & 467 & 173.777 & 0.000 \\
\hline Zscore (Forest_coverage_level_\%) & 27.550 & 2 & 0.905 & 467 & 30.454 & 0.000 \\
\hline Zscore (Forest_management_projects_ha) & 175.804 & 2 & 0.365 & 467 & 481.164 & 0.000 \\
\hline Zscore: (Ünemployed_persons) & 0.836 & 2 & 0.090 & 467 & 9.254 & 0.000 \\
\hline Zscore (Average_wage_EUR) & 55.498 & 2 & 0.609 & 467 & 91.106 & 0.000 \\
\hline
\end{tabular}


The ANOVA table shows that the values of $\mathrm{F}$ for forest management projects, heat prices and average wages are the highest. It can be argued that these indicators are the basis for classifying data sets into clusters, thus providing a basis for further regional analysis. After obtaining these results, the procedure for determining cluster centers is performed (Table 5), i.e., the singled-out indicators are indicated as the most important for a particular cluster and characterized it.

Table 5. The results of final cluster centers determination.

\begin{tabular}{cccc}
\hline & $\mathbf{1}$ & $\mathbf{2}$ & $\mathbf{3}$ \\
\hline Zscore (Costs_for_biomass_EUR) & -0.25051 & -0.21730 & -0.07046 \\
Zscore (Costs_for_gas_EUR) & -0.28372 & -0.16977 & -0.21327 \\
Zscore (Costs_for_social_allowance_th_EUR) & -0.17768 & -0.00086 & -0.35495 \\
Zscore: Municipal_budget_ & -0.31265 & -0.24692 & -0.22943 \\
expenditures_th_EUR & & & \\
Zscore: Municipal_budget_revenues_th_EUR & -0.32151 & -0.24909 & -0.22918 \\
Zscore (Personal_income_tax_revenues_EUR) & -0.31481 & -0.29682 & -0.18539 \\
Zscore (heat_price_euro_ct_kWh) & -0.35659 & 0.68760 & -0.64319 \\
Zscore (Forest_coverage_level_\%) & 1.00732 & -0.21547 & 0.22887 \\
Zscore (Forest_management_projects_ha) & 3.02849 & -0.30700 & -0.08453 \\
Zscore: (Unemployed_persons) & -0.30456 & -0.16675 & -0.28244 \\
Zscore (Average_wage_EUR) & -0.17456 & -0.60067 & 0.41051 \\
\hline
\end{tabular}

Cluster centers are related to previously identified economic, social, and environmental assumptions. The center of the first cluster is forest management projects, and the level of forest cover is also positive. The center of the second cluster is the price of heat, which is attributed to the economic outlook. The center of the third cluster is the average wage assigned to the social perspective data group. In the first case the results of the early period-2008 have been analyzed (Figure 1). In this case the regions are distributed into the second and the third clusters. There is no precedent of the first cluster which would characterize so far relatively passive municipalities. The major part of the municipalities belongs to the second cluster. As has been investigated before, the municipalities of the second cluster are characterized by the use of fossil resources and relatively lower analyzed indicators. The major part of the municipalities located in the Eastern Lithuania which have abundant biomass resources in their disposition belong to the third cluster. Varena, Mazeikiai, Ignalina municipalities (Group A) ought to be attributed to the municipalities which use biomass relatively abundantly. Other municipalities such as Prienai, Rokiskis, Kelme, Svencionys (Group B) municipalities are characterized by big forest covers and strong sector of biomass preparation, however the amounts of biomass consumed by them during the analyzed period were not marked. Other municipalities are attributed to the second cluster. Nearly all the municipalities are in Middle Lithuania excluding several individual municipalities in the Western and Eastern Lithuania. The only observed exception is Panevezys City Municipality (Group C) in which biomass was used relatively abundantly, although due to the size of the municipality no biomass preparation sector of a wide scale was created. Excluding Lazdijai, Sakiai, Zarasai (Group D) municipalities for the production of heat energy the absolute majority of the municipalities of the second cluster were using natural gas. The mentioned municipalities although they had abundant resources of biomass and were using them for energy generation had not managed to exploit the natural resources enjoyed by them on a wider scale.

In 2014, it was noticeable significant progress in the use of biomass. The number of regions in the third cluster increased significantly, especially in Western Lithuania (Figure 2). However, progress in Eastern Lithuania has stalled and regional municipalities have been included in the first cluster. There is a noticeable improvement in the situation in Central Lithuania due to large capital investments-four municipalities belonging to the third cluster have invested over 30 million EUR in biomass energy facilities. This has more than halved reduced the cost of heat [49.50]. Decreasing unemployment contributed to 
the faster progress of the regions also, the areas of uncultivated land in Western Lithuania decreased. 2014 can be considered a transitional period when regions are developing in a fragmented way.

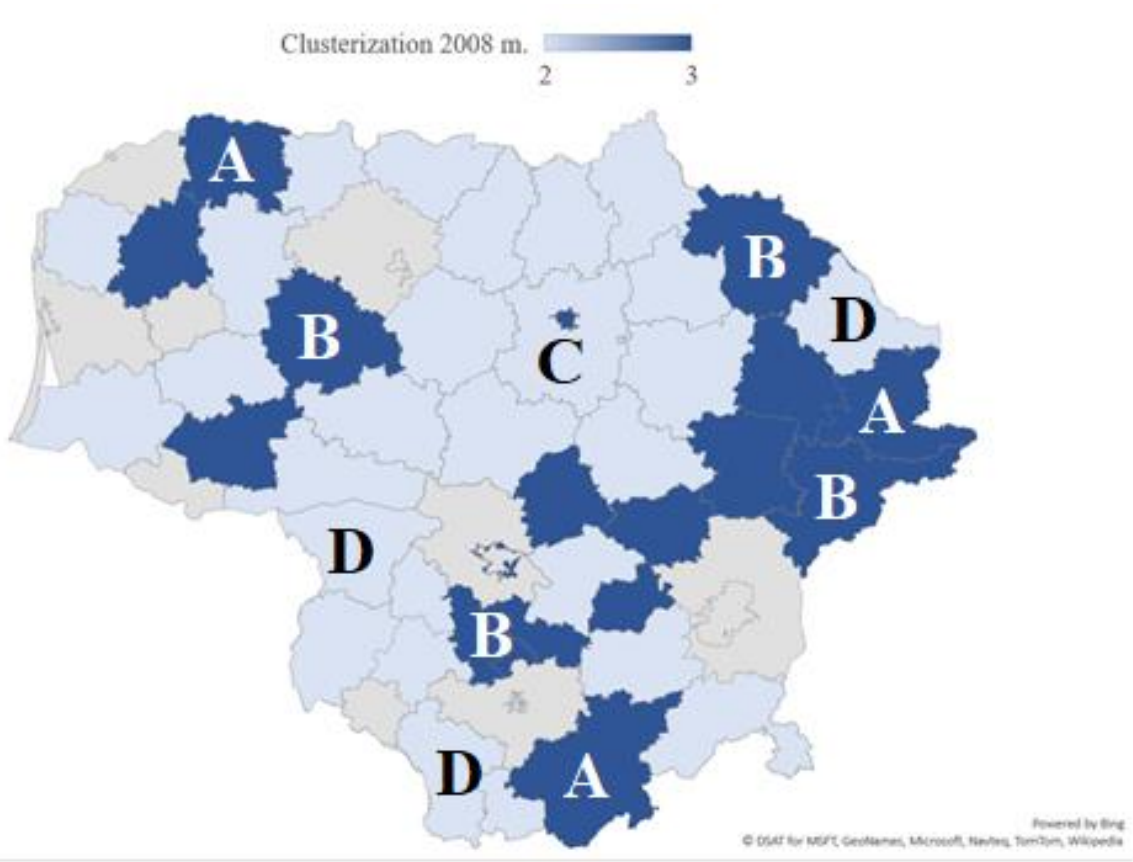

Figure 1. The results of clustering applying clusters analysis of 2008.

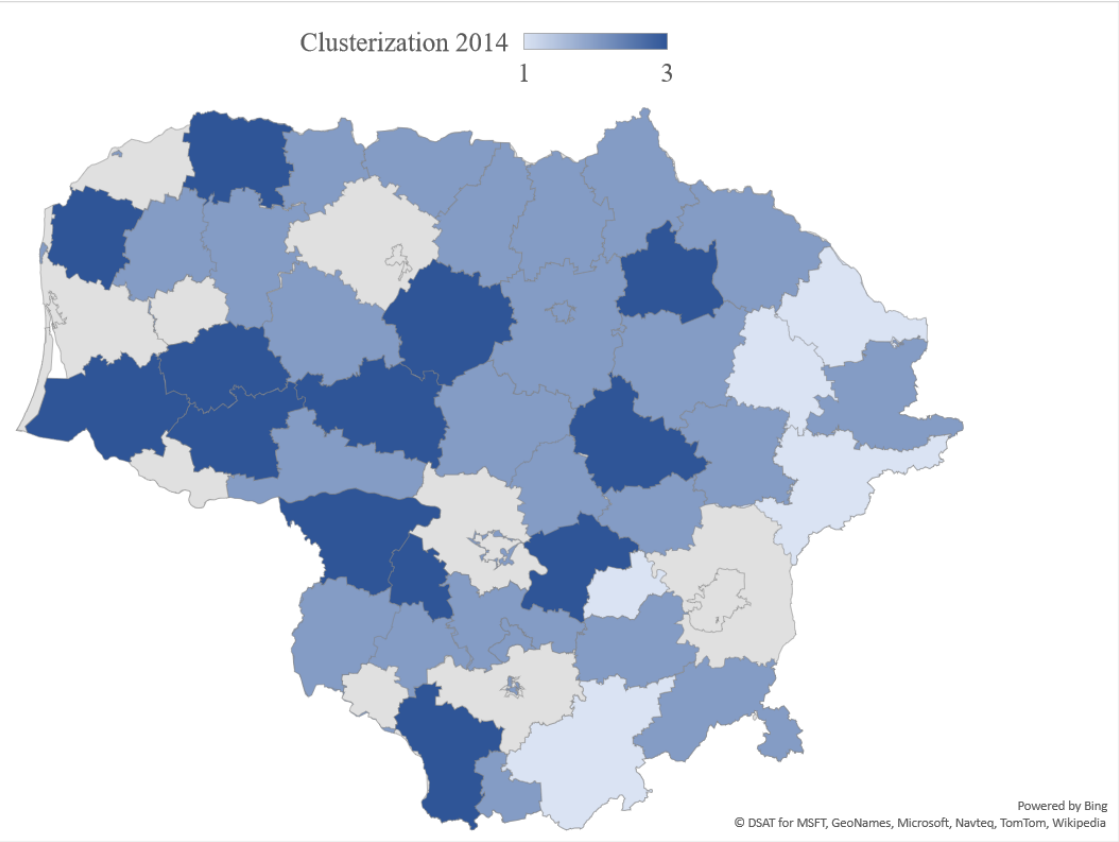

Figure 2. The results of clustering applying clusters analysis of 2014.

The results of 2017 have been presented likewise (Figure 3). In this case the effect of biomass conversion is clearly visible - the number of municipalities which have been attributed to the third cluster has grown significantly. Nearly in the whole Middle Lithuania excluding the Kedainiai District Municipality conversion effect has occurred-the municipalities have progressed to the use of biomass, improving the other analyzed indicators in this way as well. 


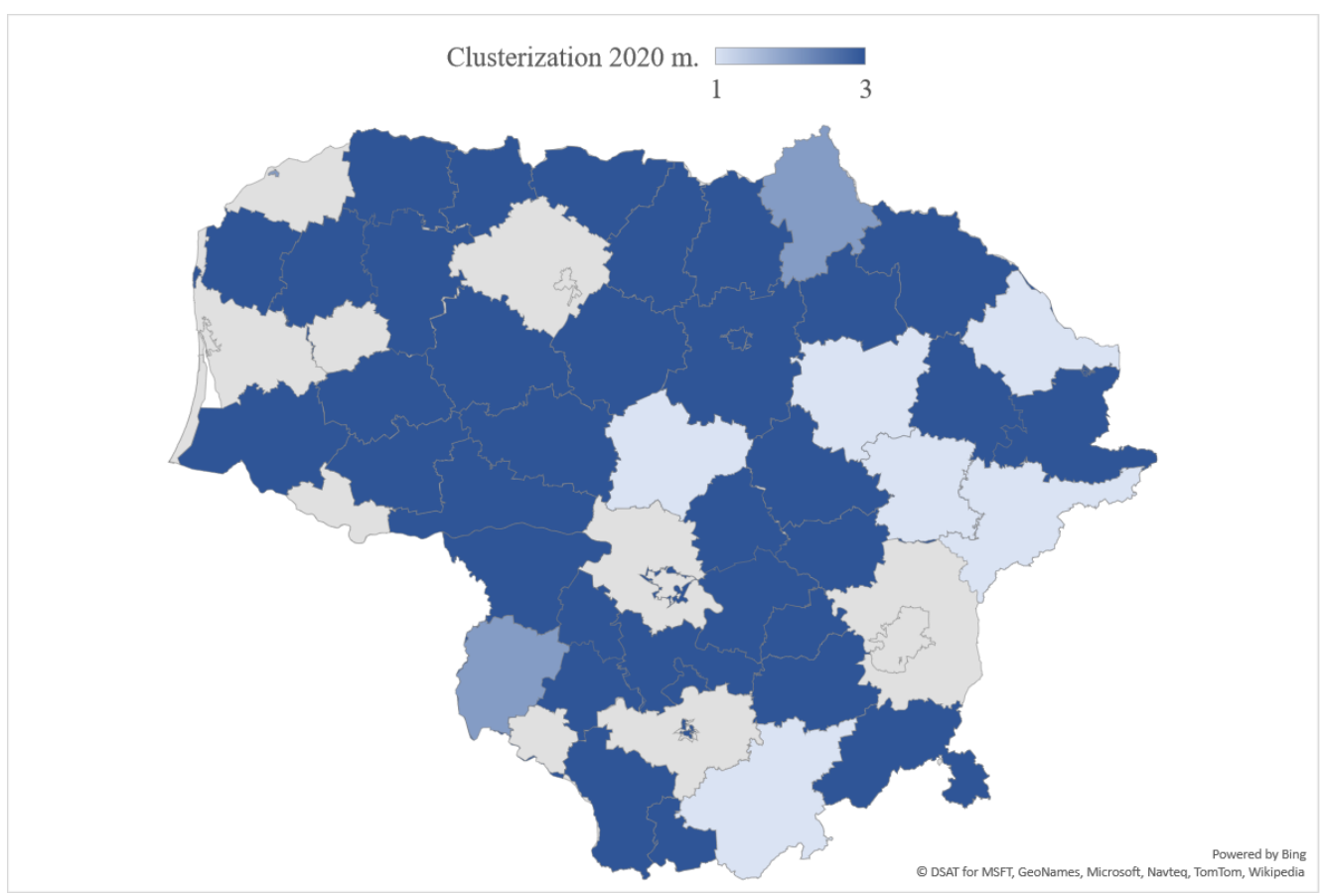

Figure 3. The results of clustering applying clusters analysis of 2020.

In comparison with the period before a decade only three municipalities the results of which are attributed to the second cluster have remained. In these municipalities biomass makes the main share in the general consumption of fuel, but these municipalities have no big own fuel resources and this has hindered the creation of strong biomass preparation sector. Inter alia these municipalities have inveterate problems of unemployment, the level of salaries is also low and the heat price due to the lack of efficiency of fuel use is high. During the analyzed period a situation which significantly increased the number of municipalities belonging to the first cluster has arisen. It indicates that these municipalities have not managed to avail of the enjoyed advantages (in the form of resources) via the creation of positive impact on the region and the society. Even though these municipalities are using biomass in the major part of cases, have abundant resources of this fuel, the sector of fuel preparation had not been created in them, they have not managed to reduce the number of the payees of welfare benefits and create well paid workplaces. This has reduced the competitiveness of the municipalities, although a decade before they were among the leaders. This enables to state that the disability of these municipalities to encourage the business entities to develop the processing of natural resources into biomass has reduced the attractiveness of these municipalities among both the society and the business entities.

In summary, the use of biomass has significantly improved the situation in the regions. However, a gap has emerged between regions that are moving in the direction of progress and those that have stuck to outdated energy production methods. The use of biomass correlates with the solution of social problems-the unemployment rate, the number of long-term unemployed persons, and allowance for this group have decreased. The use of biomass did not worsen the situation of forests, on the contrary, it reduced the area of derelict land that was later used for agricultural activities. The creation of the biomass energy sector has made it possible to expand the use of renewable resources in Lithuania, thus placing the country in a leading position in the European Union. Cluster analysis has shown that significant progress has been made over the decade in converting regional energy systems. In some cases, municipalities that were ranked among the innovators were left out due to stalled progress. The data analyzed by clusters showed that municipalities drastically changed their energy system by purchasing many parts of fuel, and the analysis of clusters showed that such municipalities are leaders in the fields of energy and social cohesion. 


\section{Conclusions}

The impact of clustering of biomass sector encompasses microeconomic and macroeconomic factors. The impact of biomass clustering on microeconomic level manifests itself in three main aspects. First-decentralization of power generation in the region. The employment of biomass creates the conditions to diversify the power market in the region, thus increasing the competitiveness of the locality. Second-the increased level of innovativeness. The activity of the biomass cluster is constantly innovated, thus forcing other power industry structures to maintain high level of efficiency. Last-the springing up of new business entities serving the cluster. The constant necessity to provide biomass and maintain a smooth supply chain creates the conditions to establish new SMEs entities. The impact created by the clustering of biomass sector on the macroeconomic level is concentrated on the following trends: the growth of energetic safety, the improvement of environmental situation and the positive economic consequences resulting from it, the improving life quality and social situation in the regions. By diversifying the energy system of the region, a biomass cluster increases the energetic safety level, as the cluster activity enables to avoid the external sabotage actions appearing due to the unexpected interruptions of energy resources supply and the inadequately growing prices of the resources. By employing organic waste which in certain cases may have negative impact on environment, economic value is extracted and cleaner dwelling environment is created. The clustering of biomass enables to create new jobs in the whole supply chain of biomass thus reducing the scale of social problems and creating an independent, ambitious and satisfied society.

During the cluster analysis while investigating the statistical indicators of the regions it has been stated that the regions are being fragmented according to the type of the used fuel and the impact created by this solution on other levels of economy. The municipalities using fossil fuel acquire less income into their budgets, collect less personal income tax and their population buys thermal power for a higher price. The situation is opposite in the municipalities using biomass-in them significantly more personal income tax is collected from the sector, the heat price is significantly less, thus indicating the opportunities of the populations of these municipalities to save means or redirect them to other directions. During the change of the analyzed period the structure of clustering changes as well-the regions which had progressed to the use of biomass were significantly improving their results on the economic and social plane. It has been investigated that the regions using biomass increase the level of the received income, ipso facto, the conditions for bigger expenses are created in them. The indicators of the registered unemployed and the expenses for welfare benefits in the municipalities using fossil fuel in comparison with the results of other municipalities are markedly bigger and also inversely proportional to the dynamics of employment of biomass. The municipalities in which the level of forest cover is high and which are implementing projects of forest management on a vast scale are not able to multiply the created positive impact and to spread it wider to economic and social spheres.

Author Contributions: Conceptualization, M.S. and J.S.; methodology, M.S. and V.N.; software, M.S. and V.N.; validation, M.S. and V.N.; formal analysis, M.S. and J.S.; investigation, M.S.; resources Y.B. and J.N.; data curation, Y.B. and J.N.; writing-original draft preparation, M.S. writing-review and editing, Y.B. and J.S.; visualization, M.S.; supervision, J.S.; project administration, Y.B.; funding acquisition, Y.B. and J.S. All authors have read and agreed to the published version of the manuscript.

Funding: This research received no external funding.

Institutional Review Board Statement: Not applicable.

Informed Consent Statement: Not applicable.

Data Availability Statement: Not applicable.

Conflicts of Interest: The authors declare no conflict of interest. 


\section{References}

1. Caputo, A.C.; Palumbo, M.; Pelagagge, P.M.; Scacchia, F. Economics of biomass energy utilization in combustion and gasification plants: Effects of logistic variables. Biomass Bioenergy 2005, 28, 35-51. [CrossRef]

2. Kulcar, B.; Goricanec, D.; Krope, J. Economy of exploiting heat from low-temperature geothermal sources using a heat pump. Energy Build. 2008, 40, 323-329. [CrossRef]

3. Wünsch, K.; Gruber, S.; Claupein, W. Profitability analysis of cropping systems for biogas production on marginal sites in southwestern Germany. Renew. Energy 2012, 45, 213-220. [CrossRef]

4. Ruzzenenti, F.; Bravi, M.; Tempesti, D.; Salvatici, E.; Manfrida, G.; Basosi, R. Evaluation of the environmental sustainability of a micro CHP system fueled by low-temperature geothermal and solar energy. Energy Convers. Manag. 2014, 78, 611-616. [CrossRef]

5. Karimi, S.; Mansouri, S. A comparative profitability study of geothermal electricity production in developed and developing countries: Exergoeconomic analysis and optimization of different ORC configurations. Renew. Energy 2018, 115, 600-619. [CrossRef]

6. Herder, P.M.; Stikkelman, R.M. Methanol-based industrial cluster design: A study of design options and the design process. Ind. Eng. Chem. Res. 2004, 43, 3879-3885. [CrossRef]

7. Andersson, V.; Broberg, S.; Hackl, R. Integrated Algae Cultivation for Biofuels Production in Industrial Clusters; Linköping University Electronic Press: Linköping, Sweden, 2011.

8. Andersson, V.; Broberg, S.; Hackl, R. Integrated algae cultivation for municipal wastewater treatment and biofuels production in industrial clusters. In Proceedings of the World Renewable Energy Forum (WREF), Denver, CO, USA, 13-17 May 2012 ; pp. 13-17.

9. Tomei, J.; Upham, P. Argentine clustering of soy biodiesel production: The role of international networks and the global soy oil and meal markets. Open Geogr. J. 2011, 4, 45-54. [CrossRef]

10. Hackl, R.; Harvey, S. Framework methodology for increased energy efficiency and renewable feedstock integration in industrial clusters. Appl. Energy 2013, 112, 1500-1509. [CrossRef]

11. De, S.; Assadi, M. Impact of cofiring biomass with coal in power plants-A techno-economic assessment. Biomass Bioenergy 2009, 33, 283-293. [CrossRef]

12. Pirraglia, A.; Gonzalez, R.; Saloni, D.; Denig, J. Technical and economic assessment for the production of torrefied ligno-cellulosic biomass pellets in the US. Energy Convers. Manag. 2013, 66, 153-164. [CrossRef]

13. Klein, B.C.; Chagas, M.F.; Junqueira, T.L.; Rezende MC, A.F.; de Fátima Cardoso, T.; Cavalett, O.; Bonomi, A. Techno-economic and environmental assessment of renewable jet fuel production in integrated Brazilian sugarcane biorefineries. Appl. Energy 2018, 209, 290-305. [CrossRef]

14. Gupta, A.; Saini, R.P.; Sharma, M.P. Steady-state modelling of hybrid energy system for off grid electrification of cluster of villages. Renew. Energy 2010, 35, 520-535. [CrossRef]

15. Theo, W.L.; Lim, J.S.; Ho, W.S.; Hashim, H.; Lee, C.T.; Muis, Z.A. Optimisation of oil palm biomass and palm oil mill effluent (POME) utilisation pathway for palm oil mill cluster with consideration of BioCNG distribution network. Energy 2017, 121, 865-883. [CrossRef]

16. Atkins, M.J.; Walmsley, M.R.; Walmsley, T.G. Integration of new processes and geothermal heat into a wood processing cluster. Clean Technol. Environ. Policy 2016, 18, 2077-2085. [CrossRef]

17. Tabas, J.; Beranová, M.; Vavřina, J. Barriers to development of the Innovation potential in the small and medium-sized enterprises. Acta Univ. Agric. Et Silvic. Mendel. Brun. 2014, 59, 447-458. [CrossRef]

18. Trianni, A.; Cagno, E.; Farné, S. Barriers, drivers and decision-making process for industrial energy efficiency: A broad study among manufacturing small and medium-sized enterprises. Appl. Energy 2016, 162, 1537-1551. [CrossRef]

19. Lund-Thomsen, P.; Lindgreen, A.; Vanhamme, J. Industrial clusters and corporate social responsibility in developing countries: What we know, what we do not know, and what we need to know. J. Bus. Ethics 2016, 133, 9-24. [CrossRef]

20. Veleva, V.; Todorova, S.; Lowitt, P.; Angus, N.; Neely, D. Understanding and addressing business needs and sustainability challenges: Lessons from Devens eco-industrial park. J. Clean. Prod. 2015, 87, 375-384. [CrossRef]

21. Madrid-Guijarro, A.; Garcia, D.; Van Auken, H. Barriers to innovation among Spanish manufacturing SMEs. J. Small Bus. Manag. 2009, 47, 465-488. [CrossRef]

22. André, C.L.; Cristofari, C. Regional policy to increase the local brand attractiveness-the case of cap energies-Corsica business cluster in renewable energy field. Int. J. Manag. Excell. 2014, 2, 270-276. [CrossRef]

23. Dasappa, S. Potential of biomass energy for electricity generation in sub-Saharan Africa. Energy Sustain. Dev. 2011, 15, 203-213. [CrossRef]

24. Krupa, J.; Burch, S. A new energy future for South Africa: The political ecology of South African renewable energy. Energy Policy 2011, 39, 6254-6261. [CrossRef]

25. Filippova, M.K.; Mindlin, Y.B.; Litvinenko, I.L.; Kucherov, A.V.; Shichiyakh, R.A.; Prokhorova, V.V. Rationale for the Use of the Cluster Approach to the Formation of Localities in the Regional Economic System. Int. Rev. Manag. Mark. 2016, 6, $20-26$.

26. Kiriyama, E.; Kajikawa, Y. A multilayered analysis of energy security research and the energy supply process. Appl. Energy 2014, 123, 415-423. [CrossRef]

27. Akella, A.K.; Saini, R.P.; Sharma, M.P. Social, economical and environmental impacts of renewable energy systems. Renew. Energy 2009, 34, 390-396. [CrossRef] 
28. Wei, M.; Patadia, S.; Kammen, D.M. Putting renewables and energy efficiency to work: How many jobs can the clean energy industry generate in the US? Energy Policy 2010, 38, 919-931. [CrossRef]

29. Suzuki, K.; Tsuji, N.; Shirai, Y.; Hassan, M.A.; Osaki, M. Evaluation of biomass energy potential towards achieving sustainability in biomass energy utilization in Sabah, Malaysia. Biomass Bioenergy 2017, 97, 149-154. [CrossRef]

30. Statistics Lithuania. Rodikliu Duomenu Bazè. Available online: https:/ / osp.stat.gov.lt/statistiniu-rodikliu-analize\#/ (accessed on 3 March 2021).

31. The State Tax Inspectorate (STI). Mokesčiu ir Kitų ı̨moku ? Biudžetus Apyskaita 2009 m. Sausio 1 d; Valstybinė Mokesčiu Inspekcija: Vilnius, Lithuania, 2020.

32. Lithuanian District Heating Association (LDHA). Šilumos Tiekimo Bendroviu 2008 Metu Ūkinės Veiklos Apžvalga; Lietuvos Šilumos Tiekeju Asociacija: Vilnius, Lithuania, 2020.

33. Baltpool. Tiekimo Kaina Pagal Regionus. Available online: https://www.baltpool.eu/lt/tiekimo-kaina-pagal-regionus / (accessed on 3 March 2021).

34. National Energy Regulatory Council. Atviri Duomenys. Available online: https://www.regula.lt/Puslapiai/bendra/Atviriduomenys.aspx (accessed on 3 March 2021).

35. Lithuanian State Forest Service. Mišku Naudojimas ir Statistika. Available online: http://www.amvmt.lt/index.php/ miskotvarka-misko-naudojimas-ir-misku-ukio-statistika (accessed on 3 March 2021).

36. Kaufman, L.; Rousseeuw, P.J. Finding Groups in Data: An Introduction to Cluster Analysis; John Wiley \& Sons: Hoboken, NJ, USA, 2009; Volume 344.

37. Yim, O.; Ramdeen, K.T. Hierarchical cluster analysis: Comparison of three linkage measures and application to psychological data. Quant. Methods Psychol. 2015, 11, 8-21. [CrossRef]

38. Kembe, M.M.; Onoja, A.A. Cluster Analysis of Macroeconomic Indices. Res. Rev. J. Stat. Math. Sci. 2017, 3, 5-15.

39. Sangalli, L.M.; Secchi, P.; Vantini, S.; Vitelli, V. K-mean alignment for curve clustering. Comput. Stat. Data Anal. 2010, 54, 1219-1233. [CrossRef]

40. Aghabozorgi, S.; Seyed Shirkhorshidi, A.; Ying Wah, T. Time-series clustering-A decade review. Inf. Syst. 2015, 53, 16-38. [CrossRef]

41. Bowden, N.; Payne, J.E. Sectoral analysis of the causal relationship between renewable and non-renewable energy consumption and real output in the US. Energy Sources Part B Econ. Plan. Policy 2010, 5, 400-408. [CrossRef]

42. Brandmaier, A.M. pdc: An R package for complexity-based clustering of time series. J. Stat. Softw. 2015, 67, 1-23. [CrossRef]

43. Zhang, X.; Mei, C.; Chen, D.; Li, J. Feature selection in mixed data: A method using a novel fuzzy rough set-based information entropy. Pattern Recognit. 2016, 56, 1-15. [CrossRef]

44. Arora, P.; Varshney, S. Analysis of k-means and k-medoids algorithm for big data. Procedia Comput. Sci. 2016, 78, 507-512. [CrossRef]

45. Szekely, G.J.; Rizzo, M.L. Hierarchical clustering via joint between-within distances: Extending Ward's minimum variance method. J. Classif. 2005, 22, 151-183. [CrossRef]

46. Zhao, Y.; Karypis, G.; Fayyad, U. Hierarchical clustering algorithms for document datasets. Data Min. Knowl. Discov. 2005, 10, 141-168. [CrossRef]

47. Keogh, E.; Lin, J. Clustering of time-series subsequences is meaningless: Implications for previous and future research. Knowl. Inf. Syst. 2005, 8, 154-177. [CrossRef]

48. Murtagh, F.; Legendre, P. Ward's hierarchical agglomerative clustering method: Which algorithms implement Ward's criterion? J. Classif. 2014, 31, 274-295. [CrossRef]

49. Rezankova, H. Cluster analysis of economic data. Statistika 2014, 94, 73-86.

50. Montero, P.; Vilar, J.A. TSclust: An R package for time series clustering. J. Stat. Softw. 2014, 62, 1-43. [CrossRef]

51. Han, J.; Kamber, M.; Pei, J. 10-cluster analysis: Basic concepts and methods. In Data Mining. Concepts and Techniques, 3rd ed.; Morgan Kauffman Publishers: Waltham, MA, USA, 2014; pp. 443-495.

52. Saini, S.; Rani, P. A survey on STING and CLIQUE grid based clustering methods. Int. J. Adv. Res. Comput. Sci. 2017, 8, 1510-1512.

53. Cheng, W.; Wang, W.; Batista, S. Grid-based clustering. In Data Clustering; Chapman and Hall: New York, NY, USA; CRC: Boca Raton, FL, USA, 2018; pp. 128-148.

54. Deng, C.; Song, J.; Sun, R.; Cai, S.; Shi, Y. GRIDEN: An effective grid-based and density-based spatial clustering algorithm to support parallel computing. Pattern Recognit. Lett. 2018, 109, 81-88. [CrossRef]

55. McLachlan, G.; Peel, D. Finite Mixture Models; John Wiley \& Sons: Hoboken, NJ, USA, 2004.

56. Raftery, A.E.; Dean, N. Variable selection for model-based clustering. J. Am. Stat. Assoc. 2006, 101, 168-178. [CrossRef]

57. Dias, J.G.; Vermunt, J.K. A bootsrap-based aggregate classifier formodel-based clustering. Comput. Stat. 2008, 23, 643-659. [CrossRef]

58. McParland, D.; Gormley, I.C. Model based clustering for mixed data: ClustMD. Adv. Data Anal. Classif. 2016, 10, 155-169. [CrossRef]

59. McNicholas, P.D. Model-based clustering. J. Classif. 2016, 33, 331-373. [CrossRef]

60. Viswanath, P.; Pinkesh, R. 1-dbscan: A fast hybrid density based clustering method. In Proceedings of the IEEE 18th International Conference on Pattern Recognition (ICPR'06), Hong Kong, China, 20-24 August 2006; Volume 1, pp. 912-915. 
61. Amini, A.; Wah, T.Y.; Saybani, M.R.; Yazdi, S.R.A.S. A study of density-grid based clustering algorithms on data streams. In Proceedings of the IEEE 2011 Eighth International Conference on Fuzzy Systems and Knowledge Discovery (FSKD), Shanghai, China, 26-28 July 2011; Volume 3, pp. 1652-1656.

62. Mai, S.T.; He, X.; Feng, J.; Plant, C.; Böhm, C. Anytime density-based clustering of complex data. Knowl. Inf. Syst. 2015, 45, 319-355. [CrossRef]

63. Wu, B.; Wilamowski, B.M. A fast density and grid based clustering method for data with arbitrary shapes and noise. IEEE Trans. Ind. Inform. 2016, 13, 1620-1628. [CrossRef]

64. Brown, D.; Japa, A.; Shi, Y. A Fast Density-Grid Based Clustering Method. In Proceedings of the IEEE 9th Annual Computing and Communication Workshop and Conference (CCWC), Las Vegas, NV, USA, 7-9 January 2019; pp. 48-54.

65. Yeung, K.Y.; Fraley, C.; Murua, A.; Raftery, A.E.; Ruzzo, W.L. Model-based clustering and data transformations for gene expression data. Bioinformatics 2001, 17, 977-987. [CrossRef] [PubMed]

66. Malsiner-Walli, G.; Frühwirth-Schnatter, S.; Grün, B. Model-based clustering based on sparse finite Gaussian mixtures. Stat. Comput. 2016, 26, 303-324. [CrossRef] [PubMed]

67. Augustyński, I.; Laskoś-Grabowski, P. Clustering macroeconomic time series. Econometrics 2018, 22, 74-88. [CrossRef]

68. Bansal, A.; Sharma, M.; Goel, S. Improved k-mean clustering algorithm for prediction analysis using classification technique in data mining. Int. J. Comput. Appl. 2017, 157, 0975-8887. [CrossRef]

69. Dias, J.G.; Ramos, S.B. Dynamic clustering of energy markets: An extended hidden Markov approach. Expert Syst. Appl. 2014, 41, 7722-7729. [CrossRef]

70. Selvakumar, J.; Lakshmi, A.; Arivoli, T. Brain tumor segmentation and its area calculation in brain MR images using K-mean clustering and Fuzzy C-mean algorithm. In Proceedings of the IEEE-International Conference on Advances in Engineering, Science and Management (ICAESM), Nagapattinam, India, 30-31 March 2012; pp. 186-190. 